\title{
ABRASION OF TEETH IN POPULATION GROUPS FROM HISTORICAL PERIODS IN THE REGION OF FORMER YUGOSLAVIA
}

\author{
DinKa MuCiĆ AND MARIJA ĐuRIĆ-SREJIĆ \\ Institute of Anatomy, Faculty of Stomatology, University of Belgrade, Dr Subotića 4/II, Belgrade 110 $0^{00}$, Yugoslavia (D.M.) and Institute \\ of Anatomy, Faculty of Medicine, University of Belgrade, Dr Subotica 4/II, Belgrade 110
}

ABSTRACT This study investigated the frequency, type, and degree of abrasion on permanent teeth from 694 skulls from archeological sites dating from the beginning of the first century $\mathrm{AD}$ to the beginning of the twentieth century in the former Yugoslavia. The conclusions are: 1) 100\% of the specimens had dental abrasion; 2) the Roman Age and the Middle Ages teeth had a horizontal-vertical type of abrasion, while New Age teeth had a predominantly horizontal type of abrasion; and 3) Ronran Age and the Middle Ages groups had the most severe loss of dental hard tissue.

\section{INTRODUCTION}

Dental abrasion is seen in all time periods during the development of the human race, in all geographical regions, and among all races. That the type of abrasion changed with time and that abrasion was much more pronounced in prehistoric than contemporary humans is generally accepted. This change in intensity of abrasion is supported by findings on Cro-Magnon man from Djerdap and on Neanderthal man from Krapina (Živanovič, 1984). Brothwell (1965) also stated that dental abrasion was much less pronounced in recent "civilized" groups than in ancient and contemporary primitive populations.

The idea of studying dental abrasion on historical anthropological material from the geographic region of former Yugoslavia originated from the above observations. The goal was to supplement the existing knowledge about this phenomenon and to enrich it with new information. The specific aims of the study were to evaluate the frequency, the types and intensity, and the factors which contribute to the existence of dental abrasion. An additional goal was to obtain an insight into the dynamics of this phenomenon during the last twenty centuries and to observe possible differences between the ancient and the contemporary population of Yugoslavia.

\section{MATERIALS AND METHODS}

A methodological approach to the study of dental abrasion requires a clarification of the terms abrasion and attrition, because they are variously explained and applied in literature. According to some (Shafer, 1974; Colbi et al., 1979) attrition and abrasion are not synonyms. Attrition denotes a physiological wear of the dental hard tissue caused by mastication and the abrasive effect of food, while abrasion is designated as a mechanical form of attrition. According to Hillson (1986) attrition is formation of well-defined wear facets where teeth meet in chewing, often with fine parallel scratches resulting from the abrasive in food, while abrasion is a more diffuse wear occurring outside the occlusal zone, with scratches randomly oriented. Botsher (1963), defines abrasion as the normal or abnormal loss of tooth structure, caused by physiological or pathological forces, resulting from the rubbing of teeth against one another or against abrasive substances, while attrition is defined as a normal loss of dental substance caused by physiological forces. According to Botsher's (1963) definition, abrasion has a broader meaning that of Hillson (1986). Abrasion encompasses attrition as a physiological phenomenon. Therefore this paper is based on Botsher's (1963) concept of abrasion as the starting point and reports on physiological and pathological wear of dental hard tissue.

Research was done on 694 skulls of both sexes ranging between 20 and 70 years of age. Information on sex, age, and the time period from which the specimens originated was obtained from documents. Material was grouped according to historical periods. The Roman Age is represented by 218 specimens from Viminacium near Belgrade.

The Middle Ages are represented by

Table 1. Types and stages of dental abrasion in former Yugoslavia samples.

\begin{tabular}{lllcccc}
\hline \multirow{2}{*}{ Time } & Type of Abrasion & & $\begin{array}{c}\text { Stage I } \\
\text { Abrasion }\end{array}$ & $\begin{array}{c}\text { Stage II } \\
\text { Abrasion }\end{array}$ & $\begin{array}{c}\text { Stage III } \\
\text { Abrasion }\end{array}$ & $\begin{array}{c}\text { Stage IV } \\
\text { Abrasion }\end{array}$ \\
\hline \multirow{3}{*}{ Roman Era } & Horizontal & $\%$ & $\%$ & $\%$ & $\%$ & $\%$ \\
& Horizontal-vertical & 55.0 & & 87.7 & 8.2 & 4.1 \\
\multirow{2}{*}{ Middle Ages } & Horizontal & 41.7 & 47.0 & 53.0 & & \\
& Horizontal-vertical & 58.3 & & 84.8 & 13.0 & 2.2 \\
\multirow{2}{*}{ New Ages } & Horizontal & 95.0 & 43.4 & 56.6 & & \\
& Horizontal-vertical & 5.0 & & 100.0 & & \\
\hline
\end{tabular}
specimens from archeological sites in the former Yugoslavia (Vinča, Knin, Skelani, and Bobovac). The New Age is represented by 160 skulls from a sizable osteological collection in the Institute of Anatomy in Zagreb.

Dental abrasion, if present, was categorized into three types: horizontal, vertical and horizontalvertical abrasion. The horizontal type of abrasion is characterized by 


\section{TOOTH ABRASION IN Former YUgOSLAVIA}

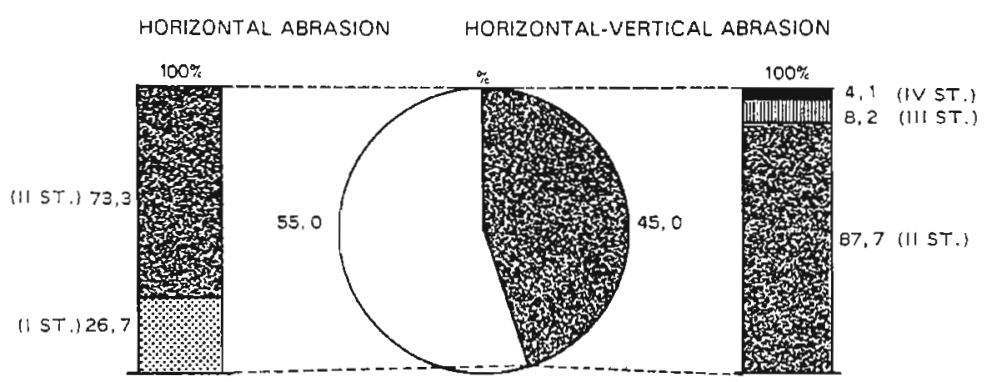

Fig. 1. Abrasion of teeth in the Roman Age sample. Numbers are given as percentages.

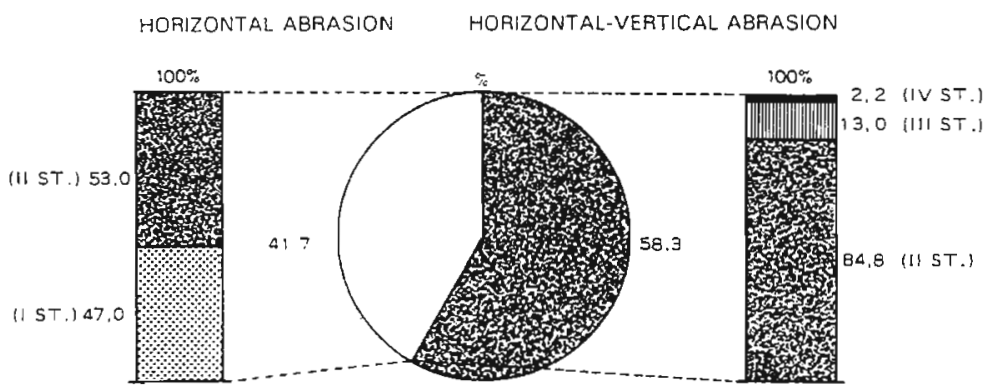

Fig. 2. Abrasion of teeth in the Middle Ages sample. Numbers are given as percentages.

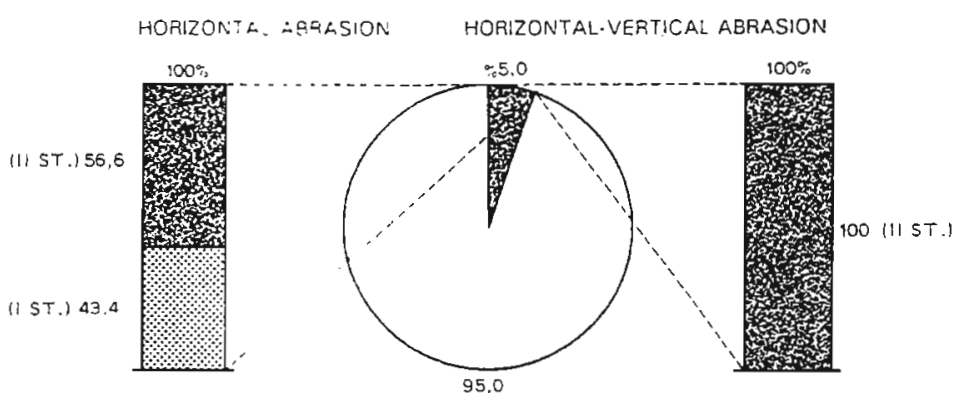

Fig. 3. Abrasion of keth in the New Age sample. Numbers are given as percentages.

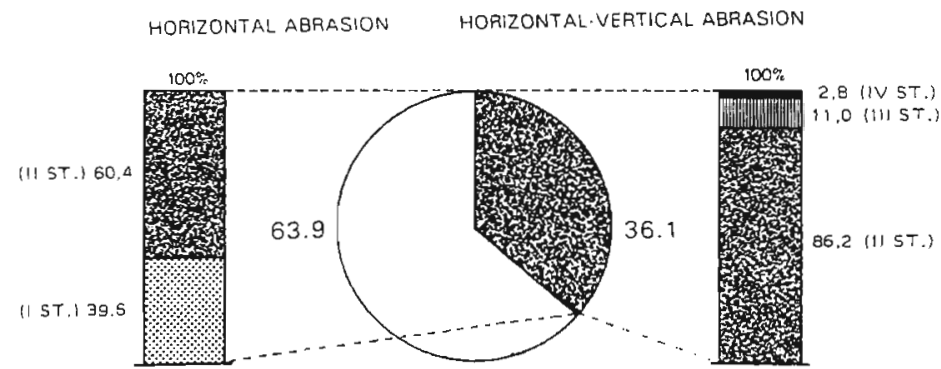

Fig. 4. Abrasion of teeth in the entire historical period. Numbers are given as percentages. the presence of a flat abraded surface which is formed in a horizontal plane. The vertical type of abrasion is characterized by abraded facets with both a vertical and a horizontal dimension. The horizontal-vertical type of abrasion contains elements of the horizontal and vertical types on the same tooth. Abrasion is categorized into four stages: Stage I (worn enamel), Stage II (wear into the dentine), Stage III (wear involving pulp exposure), and Stage IV (completely worn tooth crown).

\section{RESULTS}

Every specimen in the entire sample (100.0\%) has evidence of dental abrasion. The Roman Age sample has a higher frequency $(55.0 \%)$ of the horizontal type of dental abrasion than the horizontal-vertical type $(45.0 \%)$ (Table 1). The cases of horizontal abrasion are categorized into Stages I or II; whereas specimens with horizontal-vertical abrasion are separated into Stages II (87.7\%), III (8.2\%), and IV (4.1\%) (Table 1) (Fig. 1).

In the Middle Ages, unlike the Roman Age, the horizontal-vertical type of abrasion predominates $(58.3 \%)$ over the horizontal type $(41.7 \%)$. Within the horizontal-vertical type of abrasion, Stage II $(84.8 \%)$, Stage III (13.0\%) and Stage IV $(2.2 \%)$ were reported, while within the horizontal type only Stages I $(47.0 \%)$ and II (53.0\%) occurred (Table 1) (Fig. 2).

In the New Age sample practically all (95.0\%) cases of abrasion are of the horizontal type (Stage I at $43.4 \%$ and Stage II at $56.6 \%$ ). The remaining $5 \%$ are horizontal-vertical type (Stage II, 100.0\% ) (Table 1) (Fig. 3).

Review of the data (Table 1) shows that Stage II wear is the most frequent over the three time periods. The Roman and Middle Ages samples are similar to one another, because both have Stages III and IV abrasion. However, the New Age sample lacks these stages.

Figure 4 illustrates that over the entire period of study, the horizontal type of abrasion is present in $63.9 \%$ of the specimens and the horizontal-vertical type, in $36.1 \%$. No cases of vertical dental abrasion were found in the entire sample. Other authors (Perovic et al., 1970) have also found vertical abrasion to be less frequent than the other two types. All four stages of wear of teeth are present, with Stage II predominating. 


\section{DISCUSSION}

The dominant opinion is that causes of abrasion should be sought in food quality and type and in the mode of processing. Therefore, solid, raw food with many foreign particles (sand, pebbles, bits of animal bones), which was consumed by our ancient ancestors, resulted in intensive, often excessive tooth wear. In contrast, contemporary refined, soft, well-cooked food requires little mastication and causes only a small amount of wear on such a hard substance as tooth enamel and dentin.

This observation is supported by the work of Pedersen (1949), who found abnormal dental wear in Eskimo women was caused by chewing leather. Kandic (1976) mentions that Eskimos from the northern coast of Alaska, who ate fish, which had been preserved by covering with sand and dehydrated, had very pronounced dental abrasion. Colbi et al. (1961) cite examples of populations from India, the Philippines and Indonesia, who use the fruit of a tropical palm mixed with calcium from shells and palm leaves as an agent to provoke a feeling of well-being. This combination leads to intensive abrasion of anterior teeth.

On the other hand, Kandic (1976), indicates that dental abrasion exists even in individuals who consume very soft food, involving negligible contact rubbing of teeth during mastication. In addition, functional stress caused by non-physiological factors is a key factor in superfluous dental wear. Bunting and Hill (1940) stress that nervous stress is one of the important factors in the appearance of abrasions. Perovic et al. (1970) state that dental abrasion is quite prevalent in individuals whose occupation involves arduous physical labor, and that it very intensive in rural populations. All of the facts presented here suggest that dental abrasion has a complex and more complicated etiology than initially appears, and that research of abrasion as a function of food consumption is unilateral, but not negligible.

As the results of the study of the historical period show, dental abrasion is present in every specimen (100.0\%). This result was to be expected, keep in mind that our research encompassed adults (20-70 years of age). Even 20-year old specimens can have Stage I abrasion on the incisal edges of anterior teeth or on protuberances of molars (Fig. 5).

Research of contemporary populations of the former Yugoslavia (Perovic et al., 1970) reports the frequency of abrasion at $73.2 \%$. This pronounced contrast may be due to different methodological criteria. More likely, the decrease in abrasion confirms the opinion that abrasion was more frequent on teeth of ancient populations than on those of contemporary people. However, individual variations in the assessment of dental abrasion by various researchers possibly lead to the difference.

A detailed analysis of the types of abrasion examined in this study (Figs. 1,2 and 3) shows that in the Roman Age and the Middle Ages, the horizontal and horizontal-vertical types of abrasion were practically equally frequent. In contrast, the horizontal type of abrasion shown in Figs. 6, 7, and 8 was dominant in the New Age (95.0\%).

Results of research on modern populations are similar, with the horizontal type of abrasion predominating (73.99\%) (Perović et al., 1970). This situation is difficult to explain, considering that the type of abrasion is determined by the interrelationship of teeth within jaws during occlusion and articulation. When incisors overlap minimally, the jaw moves freely resulting in the horizontal type of abrasion. In contrast, a deep bite contributes to the occurrence of the vertical type of abrasion.

Explaining that Stage III and Stage IV tooth wear is reported only from the Roman and Middle Ages samples is easy (Fig. 9). Possible causal factors in wear of these stages were the consumption of natural, crude and abrasive

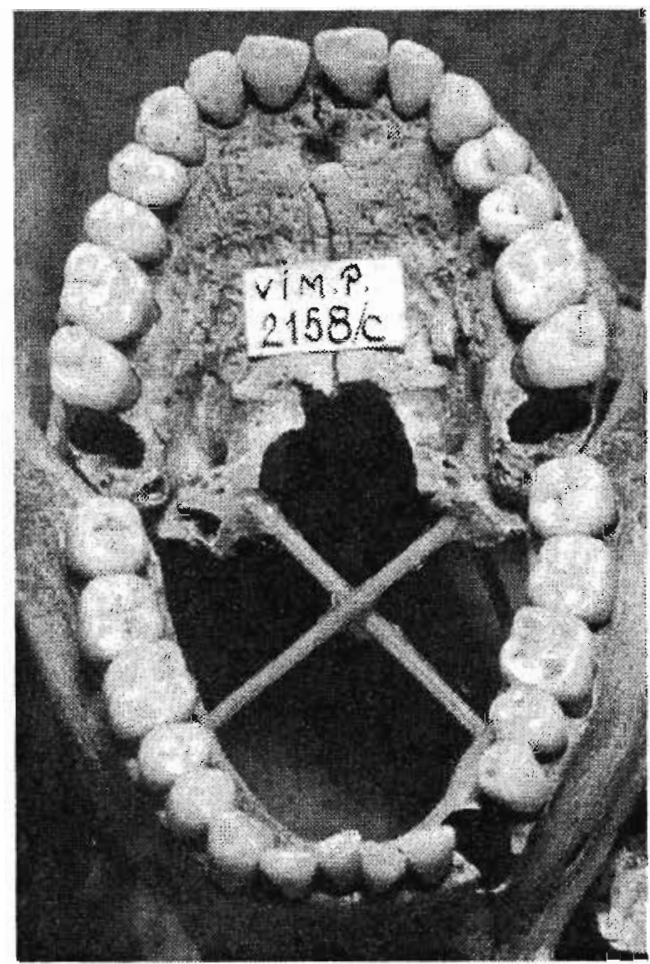

Fig. 5. Stage 1 of abrasion in an individual aged 25 years (Roman Age).

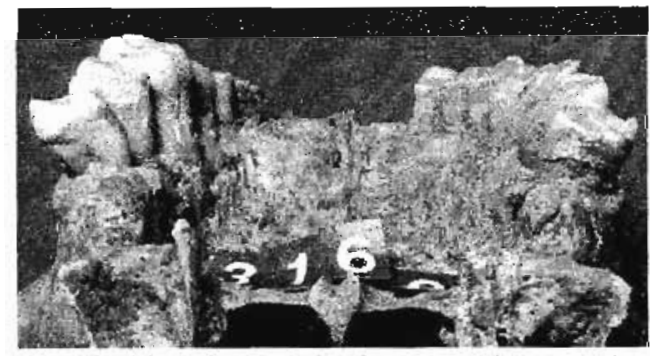

Fig. 6. Abrasion of the horizontal-vertical type, Stages II and III (Roman Age).

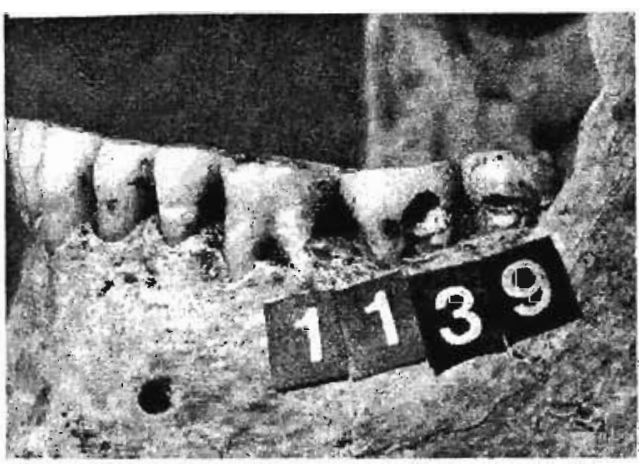

Fig. 7. Horizontal abrasion of teeth, Stage II (Roman Age). 


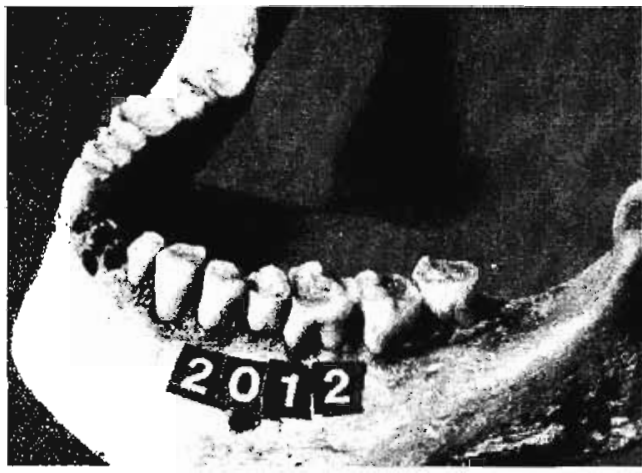

Fig. 8. Horizontal abrasion of teeth, Stages II and III (Middle Ages).

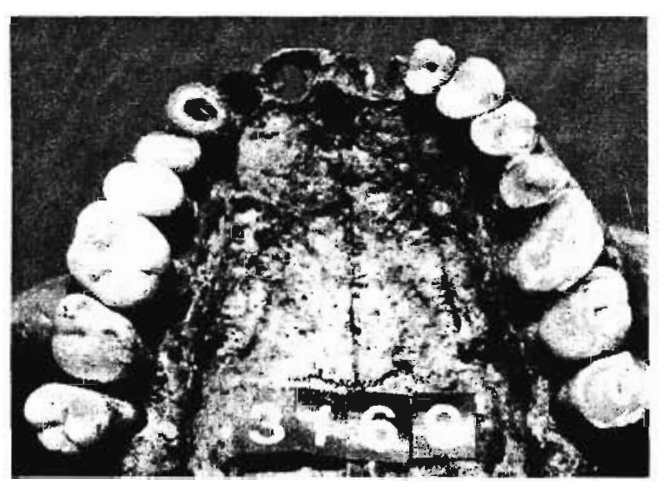

Fig. 9. Abrasion, Stages II, III, and IV (Roman Age).

food (Bisel, 1989; Trojančevič. 1986) or the presence of abrasive substances in food accompanied by powerful mastication.

Brothwell (1963) states that the baring of pulp as a consequence of attrition was present in the Stone Age, especially in the Mesolithic Era. With cultural development this phenomenon became more rare. This was confirmed in a study of Egyptian dynasties from the pre-dynastic period to the early Christian period. A similar observation was stated by Leigh (1934) and Thoma (1917).

A few remarks concerning caries and abrasion are noteworthy. Intensive tooth wear of teeth increases the susceptibility to caries development. Bisel (1989), explains the good dental health among citizens of Herculaneum based on this concept. However, caries causes destruction of the tooth crown faster than does abrasion. It may be best to consider this relationship to mean that crude food and strong mastication (which contribute to wear of teeth) assist in the self-cleansing of teeth thus decreasing the possibility of caries development. However, if the process of caries formation had already begun, the wear would be much more pronounced than if the tooth were intact. Kandic (1976) also concludes that abrasion of teeth is more frequent in individuals who have many caries, teeth with fillings, and extracted teeth.

\section{CONCLUSIONS}

Based on all of the above, the following conclusions are possible. First, the frequency of abrasion on the researched material was $100 \%$. Second, in the Roman Age and the Middle Ages the horizontal-vertical type of abrasion predominated, and in the New Age the horizontal type of abrasion predominated. Third, no cases of the vertical type of abrasion were found on any of the skeletal materials studied. Fourth, Stage II abrasions are most common in all three periods studied. Fifth, Stage III and Stage IV abrasions were observed on teeth from the Roman Age and the Middle Ages. Sixth, more intensive dental abrasion in the Roman Age and the Middle Ages samples, as compared to the New Age, is caused by of nutrition among other factors.

\section{LITERATURE CITED}

Bisel S (1988) Nutrition in first century Herculaneum, Anthropologie XXVI/l.

Boutsher C (1963) Current Clinical dental Terminology. St. Louis: CV Mosby Company.

Brothwell DR (1963) The macroscopic dental pathology of some earlier human populations. In DR Brothwell (ed.): Dental Anthropology. London: Pergamon Press, pp. 271-278.

Brothwell DR (1965) Digging up Bones: The Excavation, Treatment and Study of Human Skeletal Remains. London: William Clowes and Sons.

Bunting RW, and Hill TJ (1940) Oral Pathology, 2nd ed. Philadelphia: Lea and Febiger.

Colby RA, Kerr DA, Robinson HBG (1961) Color Atlas of Oral Pathology. Philadelphia: Lippincott Company.

Hillson S (1986) Teeth. Cambridge: Cambridge University Press.

Kandić M (1976) Prilog proučavanju abrazije zuba - Doktorska disertacija, Belgrade.

Leigh RW (1934) Notes on the stomatology and pathology of ancient Egypt, University of California, Publications in American Archaeology and Ethnology 34:1.

Pedersen PO (1949) The East Greenland Eskimo Dentition. Medd. Gronland, Kobenhaven, 142:1-256.

Perović J (1970) Abrazija zuba prema polu, starosti, zanimanju i godinama školovanja u mestu boravka. Stomatološki glasnik Srbije, Aug./Oct.

Shafer W, Hine M, Levy B (1974) A Textbook of Oral Pathology, Third edition. Philadelphia: Lippincott Company.

Thoma KN (1917) Oral diseases of ancient nations and tribes. J. Allied Dent. Soc. 12:327.

Trojančevič S (1896) Starinska srpska jela i pića, Srpski etnografski zbornik, Knjiga II, Džavna štamparija Kraljevine Srbije, Belgrade. Živanović (1984) Bolesti drevnih ljudi, Srpska Književna zadruga, Belgrade. 